GLOBAL JOURNAL OF SOCIAL SCIENCES VOL 15, 2016: 47-54

COPYRIGHT@ BACHUDO SCIENCE CO. LTD PRINTED IN NIGERIA. ISSN 1596-6216

\title{
HUMAN RESOURCE MANAGEMENT TOOL OF MOTIVATION ANDEMPLOYEES JOB SATISFACTION IN AN ORGANIZATION
}

\section{EGBE OJONG TANDU, ABEKI SUNNY OKORO, SUNDAY OFFUM OGON AND PETER TAWOR ETTA}

(Received 23 September 2016; Revision Accepted 12 October 2016)

\begin{abstract}
The main purpose of this study is to ascertain how human resources management tool of motivation can bring about employees job satisfaction in an organization with particular focus on Cross River University of Technology (CRUTECH), Calabar. The study was inform by the fact that as a scholar with interest in $\mathrm{HRM}$, it has become worrisome as regards the increasing reoccurrence of the problem of poor job satisfaction in organizations. The sample consisted of 202 employees of the university selected from a population of 802 through simple random sampling technique. The instrument used for collecting data for the study was a 20 -item questionnaire. Chi-square and correlation-co-efficient statistical methods were used to test the hypotheses. The following were the findings of the study: 1 . There is significant relationship of employees motivation on their job satisfaction (2) There is a cordial relationship between management employees relationship and employees job satisfaction. On the bases of these findings, it was concluded that motivation as a tool of Human Resource Management should be taken seriously in order to achieve employees job satisfaction in organizations.
\end{abstract}

KEYWORDS: Human Resources Management, Motivation, Employees, Job Satisfaction, Tool.

\section{INTRODUCTION}

Human Resources Management (HRM) is both a field of study and a practice. It focuses on the whole process of planning, finding, building, coordinating, utilizing work force and handling the formal system for the management of people within the organizations until and after retirement. Peretomode (2001) consider Human Resources Management as a process of bringing people and organization together so that the goals of each of them are met.

The successful management of human resources is one of the keys to the effective operation of an organization. Managers in both private and public sectors must all tap the talent of their human resources if they are to be successful. If organizations are to accomplish their objective,(Mathis and Jackson, 1982).

An organization therefore must seek to get competent people into it fold. Consequently, the human resources most be well motivated and properly managed to create job satisfaction if the organization is to achieve its goals. This implies that an organization has to plan for its current and future human resources needs.

Motivation is used to describe the complex forces, drives tension states, or other mechanisms that initiate and maintain voluntary activity directed towards the achievement of goals, (Hoyand Miskel, 1987). It is an inner state that actuates or moves. As Mathins and Jackson (1982) put it, "it is an emotion or desire, operative on a person's will and causing that person to act. Motivation", they added, "is concerned with human behaviour". It attempt to account for the

Egbe OjongTandu, Department of Political Science, College of Education, Akamkpa, Cross River State.

Abeki Sunny Okoro, Deputy Rector, International Institute of Tourism and Hospitality, Yenagoa, Bayelsa State.

Sunday Offum Ogon, Department of Political Science, College of Education, Akamkpa, Cross River State. Peter Tawor Etta, Department of Political Science, College of Education, Akamkpa, Cross River State. 
"drive" or 'wants' inside an individual rather than describing the individual's action or behaviour.

The term 'job satisfaction' has been defined in several ways. We define it as the feelings (Good or bad) that one has about the work and the environment that causes a person to say "I am satisfied with my job" (Middlemist and Hitt, 1981; Hopock, 1985). It is thus "The pleasurable or the appraisal of one's job or job experience" (Locke, 1976); an appraisal that must have taken into consideration the work content and context-a combination of psychological, physiological and environmental circumstances. Cross River University of Technology (CRUTECH), which is the focus of this study was established in 2002 as a merger of former polytechnic Calabar, College of Agriculture Obubra and newly established Ogoja Campusesas respectively.

\section{Statement of the problem}

The Cross River University of Technology (CRUTECH) as the organization under study embraces the classical theory of management as its management strategy Henry F. and Mayo E, (Cole, 1990). The management strategy emphasis is more on the structure and activities of the university and less emphasis on motivating the employees for maximum achievement for which it was set up. As a scholar of Human Resources Management, "the increasing reoccurrence of the problem of poor job satisfaction of employees in organization is disturbing. This study therefore, seeks to ascertain how Human Resources Management (HRM) tool of motivation as a determinant of job satisfaction can bring about job satisfaction among employees of CRUTECH.

\section{Literature Review/Theoretical Framework} Human Resources Management represents the discovering of personnel management over the last decade. Human Resources Management (HRM) has taken on an increasing theoretical significance as it has become part of the wider socio-logical debate concerned with new management paradigms. The point to note here is that, Human Resources Management (HRM) is an approach to management of the employment relationship with distinctive set of human resources policies and practices designed to produce specific outcomes to secure the greater commitment of employees and improve organizational performance. The present study falls in line here, as it looks at the extent to which motivation as a tool of Human Resources Management (HRM) can bring about job satisfaction of workers in an organization. The literature reviewed (Henry F. and Mayo E.) also presented the hard version and soft version of Human Resources Management (HRM). The hard version sees people as any other economic factor as a cost that must be controlled, through coercion and sanctions. Management and workers here see themselves as antagonist, suspecting each other's move. On the other hand, the soft version sees people as 'human' and thus advocate investment in training and development and the adoption of commitment strategies to ensure that highly skilled and loyal workers give the organization a competitive advantage. Management and workers see themselves as partners that must work together to achieve organizational goals and workers interest.

Evidence from the literature (Henry $F$. and Mayo E.) and findings from the studies reviewed indicate that, management of organizations tend to lay more emphasis on the structures and activities of the organizations using the classical management theory which sees management in terms of planning, organizing, commanding, coordinating and controlling. Less attention was paid on the people and their needs as the decisive factor in achieving organizational effectiveness. This study therefore seeks the extent to which motivation as a tool of human resources management can bring about job satisfaction in an organization with emphasis among CRUCTECH employees (junior employees).

The use of relevant theoretical framework is an indispensable requirement in any meaningful research work, because such a framework prevents aimless meandering.Herzberg's Dual factor theory is adopted for this study.

Herzberg's Dual factor theory has important application in Human Resources Management (HRM) and job satisfaction. It was introduced by Fredrick Herzberg in the late 1950s (Cole, 1990). His argument is based on this empirical work, that there are two separate categories or factors in the work place, those that are related to job satisfaction and those that are related to job dissatisfaction. Those factors that contribute to job satisfaction result to the job content and are called motivators or satisfiers or intrinsic factors. 
Herzberg (1996) pointed out that when motivators are present in the work situation, they lead to strong motivation, satisfaction and job performance, but do not cause dissatisfaction when they are absent. At worst, the absence of motivators can only resent in no satisfaction. The motivational factors are: Achievement, Recognition, Advancement Promotion, the work itself, possibility of professional growth and Responsibility.

The other category or factors is referred to as hygiene, dissatisfier, maintenance, or extrinsic factors. These factors are related to the work context. He maintained that if these factors (extrinsic) were present in the work situation, the employees would not necessarily be either motivated or satisfied. When these factors (extrinsic) are not forth coming, dissatisfaction occurs and the opposite of satisfaction is nosatisfaction. Herzberg identified ten hygiene factors: company policy and administration, technical supervision, interpersonal relations with supervisors, interpersonal relatives with peers, interpersonal relations with subordinates, salary, job security, personal life, working conditions, and status.

Herzberg's two factors theory has application in motivation and job satisfaction. It suggest that to motivate employees, managers should focus on the motivators while at the same time try to maintain hygiene factors at an appropriate level so as to prevent dissatisfaction. Also, the message in the theory is simple, direct and persuasive and has inspired many mangers to redesigned their jobs in order to facilitate increased motivation.

\section{METHODOLOGY Null hypotheses}

Based on the literature and theoretical framework reviewed, the following hypotheses were formulated to guide this study.

\section{Null hypothesis one}

There is no significant relationship of employees motivation on their job satisfaction.

\section{Null Hypothesis two}

There is no significant relationship of between management/employees relationship and employees job satisfaction.

\section{Source of data collection}

The questionnaire was used to collect data. The information gathered from literature reviewed informed the development of the questionnaire. In order to test and ascertain the validity and reliability of the research instrument, pre-test was first carried out on some of the employees of CRUTECH under study. The test came in a tentative questionnaire form aimed at determining the appropriate questions that would elicit the desired answers to the research questionnaire. Based on the reactions of the respondents, certain modifications were made to the research instrument.

\section{Methods of data analysis}

Data collected were analyzed using chisquare and correlation coefficient statistical methods. The samples were randomly selected from the population of the study.

\section{Data presentation, Analysis and Discussion of Findings}

The researchers used four campuses to collect the data. That is; Calabar, Obubra, Ogoja I, and Ogoja II. Two hundred junior employees were sampled randomly using 200 questionnaire. Based on the strength of the campuses, Calabargot 80, Obubra 25, Ogoja I 60 and Ogoja II 35. Out of the 200 questionnaire distributed to the respondents only 180 representing $90 \%$ were duly completed and returned. The distribution is seen as presented in table 1 below.

Table 1:Distribution of respondents who completed and returned their questionnaire according to campuses

\begin{tabular}{llllll}
\hline Campuses & Calabar & Obubra & Ogoja I & Ogoja II & Total \\
\hline $\begin{array}{l}\text { Junior } \\
\text { employees }\end{array}$ & 78 & 13 & 60 & 29 & 180 \\
\hline
\end{tabular}

Source: Fieldwork, 2016.

\section{Data analysis}

Hypothesis-by-hypothesis data analysis of results are presented here.
Hypothesis one

There is no significant relationship between employees motivation and their job 
satisfaction. This hypothesis is to test the employees motivation level and its relationship with their job satisfaction. The indices used in measuring motivation are promotion, recognition, in-service training and incentives. The responses are presented in items 1-12 of the research instrument which was used to analyzed the hypothesis. See appendix A for details.

The chi-square formula was used to test this hypothesis at (5\%) 0.05 level of significance. The general chi-square formula for calculation is:

$$
\begin{array}{cll}
\mathrm{X}^{2}= & \frac{\sum(0-\mathrm{e})^{2}}{\mathrm{e}} \\
\text { Where } \mathrm{x}^{2} & = & \text { the chi-square } \\
\sum \quad \mathrm{O} & \text { the summation sign } \\
\mathrm{E} & = & \text { the observedfrequencies } \\
& = & \text { the expected frequencies }
\end{array}
$$

The degree of freedom:

\begin{tabular}{|c|c|c|}
\hline Where df & $=$ & the numbers of degrees \\
\hline C & 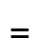 & the number of colums \\
\hline $\mathrm{R}$ & $=$ & the number of rows \\
\hline
\end{tabular}

(df) $(c-1)(R-1)$

Calculation: See Appendix B

\section{Decision Rule:}

If the $x^{2}$ calculated is greater than $x^{2}$ tabulated depending on the degree(s) of freedom and the level of significance the null hypothesis will be rejected.

\section{Decision on Null hypothesis one}

Following the decision rule as stated above, since the $x^{2}$ calculated of 46.96 is greater than the $x^{2}$ tabulated of 12.59 with six degree of freedom (df) and at 0.05 level of significance. It therefore means that we reject the null hypothesis. Thus, it can be said that, employees motivation has significant relationship on their job satisfaction.

\section{Null hypothesis two}

There is no cordial relationship between Management/Employees relationship and employees job satisfaction. This hypothesis is to test the relationship between Management/Employees and its relationship on employeesjob satisfaction. Items number 13-20 of the research instrument were used to analyzed the hypothesis. See appendix A for details.
The pearson product moment correlation coefficient statistical method was used to test this hypothesis. This is presented below.

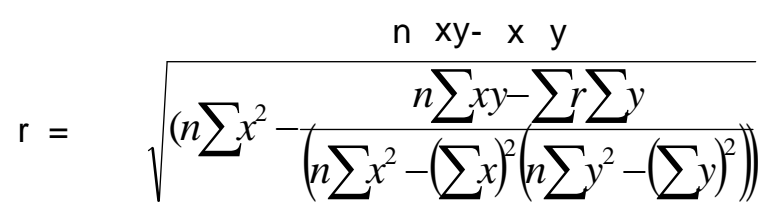
Where $r=\quad$ Pearson product corelation coefficent $\mathrm{n}=$ the number of pairs of scores
$\sum x y=$ htes sum of the product of each pairs of scores
$\sum \mathrm{x}=\quad$ the sum of $\mathrm{x}$
$\sum y \quad=\quad$ the sum of $y$
$\mathrm{x}^{2}=$ the standard deviation of
$x$ distribtuion
$\mathrm{y}^{2}=$ the standand deviation of $y$ distribution

The formula has a range of values from $1,0,1$. The value of -1 clearly indicates a negative relationship among the vaiabels while 0 shows no relationshp and 1 shows perfect relationshipbetween variables $x$ and $y$ respectively. The decision of the test is taken at $5 \%(0.05)$ level of signficance.

Calculation: See Appendix C:

\section{Decision Rule}

If the $t$ calculated is greater than the $t$ tabulated depending on the degree(s) of freedom (df) and the level of significance we reject the null hypothesis.

\section{Decision on Null hypothesis two}

Based on the decision rule since the $t$ calculated of 13.34 is greater than the $t$ tabulated of 1.96 at 178 degrees of freedom and at 0.05 level of significant, we therefore reject the null hypothesis. Thus, it can be said that, there is cordial relationship between management/employees relationship and employees job satisfaction.

\section{Discussion of Findings}

The overall objective of this study is to as certain how human resources management tool of motivation as a determinant of job satisfaction can bring about job satisfaction among junior employees in Cross River University of 
Technology (CRUTECH). To achieve the above objective, two hypothesis were postulated and tested for statistical significance on the basis of the sampled data. The findings are an expression of the application of the literature review and theoretical framework discussed in this study.

\section{Null hypothesis One:}

There is no significant relationship of employees motivation on their job satisfaction. The chi-square $x^{2}$ calculated of 46.96 is greater than the $x^{2}$ tabulated of 12.59 with six degrees of freedom (df) and at 0.05 level of significance, it therefore means that the null hypothesis was rejected. Thus, it can be said that, employees motivation has significant relationship on their job satisfaction.

\section{Null hypothesis two:}

There is no cordial relationship between management/employees relationship and employees job satisfaction.

The correlation coefficient was used for the second hypothesis. Since the t-calculated of 13.34 is greater than the t-tabulated of 1.96 at 178 degrees of freedom and at .05 significant level, we therefore reject the null hypothesis. Thus, it can be said that, there is cordial relationship between management/employees relationship and employee job satisfaction.

\section{CONCLUSION}

Based on the findings of the study, it is clear that, the two null hypotheses were rejected. Therefore, the Cross River University of Technology (CRUTECH) which is under study must reappraise her management of human resources strategy in order to effectively motivate employees to prevent the increasing reoccurrence of the problem of poor job satisfaction of staff in the university (organization). This definitely will go a long way to achieving the vision of the university which is to establish a centre of excellence with adequate qualified and motivated employees engaged in high quality teaching and research for the production of graduates that can compete with their peers anywhere in the world.

\section{RECOMMENDATIONS}

On the basis of the findings therefore, the following recommendations are inevitable: Motivation of employees is very important in humanresources management. Performance appraisal is needed to provide employees with information as a means of motivating them. Management should take a systematic training (in-service) and development programme to build the skills of current employees and help them grow to their fall potential in the university.

Finally, management of the university should provide a high quality of work life such as: Workers should be paid equitable wages and recognition for their contributions. Supervision should be minimal and should be available when needed. Workers should be involved in decisions that affect them and their job. Job security should be provided and friendly relationship with coworkers should be developed. Facilities should be provided for personal welfare and medical attention.

\section{REFERENCES}

Cole, G. A., 1990. Management: Theory and Practice. London: The Guensey Press Limited.

Herzberg, F., 1966. Work and nature of man. London: Macmillan publishing company.

Hoy, S. E and Miskel, A. M., 2005. Effects of changes in job satisfaction levels on employees turnover. New York: John Wiley and Son.

Hopock, S. E., 2006. From personnel Management to Human Resources Management. Oxford: Blackwell.

Locke, E. A., 2001. The nature and causes of job satisfaction in Dunnette, M. D. (ed). Handbook of industrial and organizational psychology. (20-25). Chicago: Rand Nenatly.

Mathis, A. D and Jackson, J. H., 2002. Personnel contemporary perspectives and applications ( $3^{\text {rd }}$ edition), St. Paul: West Publishing Company.

Middlemist, D. R andHitt, M. A., 2001. Organizational behaviour: Applied Concepts. Chicago: SRA Press.

Perotomode, V. E and Perotomode, O., 2001. Human Resources Management, Lagos: Obaroh and Ogbinaka Publishing Company. 


\section{APPENDIX A \\ RESEARCH QUESTIONNAIRE}

Please, kindly tick $(\sqrt{ })$ your position on the scale as the statement impresses you.

$\begin{array}{lll}\text { Key } & & \\ \text { AS } & - & \text { Strongly Agree } \\ \text { A } & - & \text { Agree } \\ \text { D } & - & \text { Disagree } \\ \text { SD } & - & \text { Strongly Disagree }\end{array}$

\begin{tabular}{|l|l|l|l|l|}
\hline S/N & STATEMENT & SA & D & SD \\
\hline & Promotions are made as at when due & & \\
\hline & I enjoy promotion and pay increase which I deserve & & \\
\hline Staff are always promoted when they get additional qualification. & & & \\
\hline I have won some awards for my performance & & & \\
\hline Management shows appreciation for my efforts. & & & \\
\hline Staff are hardly rewarded for their contributions to the organization. & & & \\
\hline There are ample chances for various in-service training with pay for staff. & & & \\
\hline & I enjoy in-service training provided for us by our organization. & & \\
\hline As a staff, 1 have opportunities to enhance myself through in -service training & & & \\
\hline Allowances paid are commensurate to the job & & & \\
\hline $\begin{array}{l}\text { Staff conditions of service are quite good. } \\
\text { My present monetary benefits has enhanced my job satisfaction. }\end{array}$ & & \\
\hline Staff are provided with necessary facilities to work & & & \\
\hline Management pay attention rarely to staff problems & & \\
\hline $\begin{array}{l}\text { The relationship between the junior staff and their superior is hardly } \\
\text { cordial. }\end{array}$ & & & \\
\hline $\begin{array}{l}\text { Junior staff are provided with opportunities to use their own ideas and } \\
\text { judgment on their job. }\end{array}$ & & & \\
\hline Junior staff are provided with good work conditions by management. & & \\
\hline $\begin{array}{l}\text { Junior staff are not given the opportunities to participate in decision - } \\
\text { making that affect them. }\end{array}$ & & \\
\hline Management shows sympathy on junior staff personal problems seldomly & & & \\
\hline Management provides stimulating and challenging jobs to junior staff. & & \\
\hline
\end{tabular}




\section{APPENDIX B}

\begin{tabular}{|c|c|c|c|c|c|}
\hline Motivation & \multicolumn{4}{|c|}{ Job satisfaction } & Total \\
\hline & Promotion & Recoqnition & In-service & Incentives & \\
\hline High & $20(12.78)$ & $6(2.22)$ & $15(11.11)$ & 9)13.39) & 50 \\
\hline Moderate & $2(18.14)$ & $2(17.36)$ & $11(15.78)$ & $30(19.72)$ & 71 \\
\hline Low & $24(15.08) 46$ & $10(14.42)$ & 14(13.11) & 11(16.39) & 59 \\
\hline Total & & 44 & 40 & 50 & 180 \\
\hline
\end{tabular}

$\mathrm{X}^{2}=\mathrm{e}^{\sum(0-\mathrm{e})^{2}}$

\begin{tabular}{|l|l|l|l|l|}
\hline $\mathbf{0}$ & $\mathbf{E}$ & $\mathbf{O E}$ & $\mathbf{( 0 - E )}$ & $\frac{(\mathbf{O}-\mathbf{E})^{2}}{\mathbf{e}}$ \\
\hline 20 & 12.78 & 7.22 & 52.13 & 4.08 \\
\hline 6 & 2.22 & -6.22 & 38.69 & 3.17 \\
\hline 15 & 11.11 & 3.89 & 15.13 & 1.36 \\
\hline 9 & 13.89 & -4.89 & 23.91 & 1.72 \\
\hline 2 & 18.14 & -16.14 & 260.50 & 14.39 \\
\hline 28 & 17.36 & 10.64 & 113.21 & 6.52 \\
\hline 11 & 15.78 & -4.78 & 22.85 & 1.45 \\
\hline 30 & 19.72 & 10.28 & 105.68 & 5.36 \\
\hline 24 & 15.08 & 8.92 & 75.47 & 5.76 \\
\hline 10 & 14.42 & 4.42 & 19.54 & 1.35 \\
\hline 14 & 13.11 & 0.89 & 0.79 & 0.06 \\
\hline 11 & 16.39 & -5.39 & 29.05 & 1.77 \\
\hline
\end{tabular}

$\mathrm{X}^{2}=46.96$

$\mathrm{df} \quad=\quad(\mathrm{c}-1)(\mathrm{r}-1)$

(4-1)(3-1)

$\mathrm{X}^{2} \mathrm{cal}=46.96$

$\mathrm{X}^{2} \mathrm{tab}=12.59$

Df $=6$

Level of significance $=0.5$ 


\section{APPENDIX C}

$$
\begin{aligned}
& r=\sqrt[n \sum x y-\sum x \sum y]{\left(n \sum x^{2}-\left(n \sum x y-\sum r \sum y\right.\right.} \\
& \mathrm{n} \quad=\quad 180 \\
& \sum x \quad=\quad 725 \\
& \sum \mathrm{y} \quad=\quad 715 \\
& \sum x y=64787 \\
& \sum x^{2}=65713 \\
& \sum x y^{2}=63913 \\
& 180 \times 64787-725 \times 715 \\
& r \quad=\quad \sqrt{\left(180 \times 65713-(725)^{2}\right)(180 \times 63913)-(715)^{2}} \\
& r \quad=\quad \frac{1161660-518375}{\left(11828340-525625-(11504340)-(715)^{2}\right.} \\
& r=\frac{11143285}{1242520414} \\
& r \quad=\frac{11143285}{\sqrt{1246840.17}} \\
& \begin{array}{rll}
r & = & 0.999 \\
& = & 1.00
\end{array}
\end{aligned}
$$

Converting the above $r=1.00$ to t-test, we have

$$
\begin{aligned}
& \mathrm{t}=\mathrm{r} \sqrt{\begin{array}{l}
n-2 \\
1-r^{2}
\end{array}} \\
& \text { Where } r=\quad \text { correlation coefficient } \\
& \mathrm{n}=\text { number of variables } \\
& 2=\text { is a constant } \\
& \text { df }=\mathrm{n}-2 \\
& r \quad=\quad 1.00 \sqrt{\frac{180-2}{1-(1.00)^{2}}} \\
& r \quad=\quad 1.00 \sqrt{\frac{1782}{1-1}} \\
& r=\sqrt{\frac{178}{0}} \\
& r=1.00 \times 13.34 \\
& \mathrm{t}=\mathrm{cal}=13.34 \\
& \mathrm{t} \quad=\quad \mathrm{tab}=1.96 \\
& \text { df } \quad=\quad \mathrm{N}-2=180-2=178
\end{aligned}
$$


